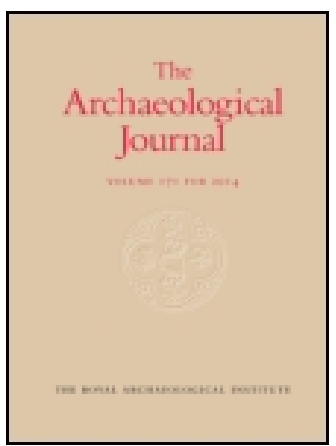

Archaeological Journal

\title{
Discoveries in the Forum
}

\section{S. Russell Forbes Ph.D.}

To cite this article: S. Russell Forbes Ph.D. (1899) Discoveries in the Forum, Archaeological Journal, 56:1, 307-318, DOI: 10.1080/00665983.1899.10852826

To link to this article: http://dx.doi.org/10.1080/00665983.1899.10852826

曲 Published online: 16 Jul 2014.

Submit your article to this journal $\widetilde{ }$

ЏII Article views: 2

Q View related articles $\asymp$ 


\title{
DISCOVERIES IN THE FORUM.
}

\author{
By S. RUSSELL FORBES, Ph.D.
}

\section{The Cremating of Cesar.}

During the month of December, 1898, the interior of the hemicycle platform of the Rostra Julia was cleared out, with the following results. The hemicycle wall of tufa, upon two first courses of travertine, shows traces of having been cased with marble, therefore the straight wall in front of it is an addition. The space between the two walls at its greatest width is 11 feet, and is occupied by an octagonal base of three steps, 10 inches, 17 inches and 11 inches high, thus forming a base 3 feet 2 inches high; this base stands on travertine blocks raised $2 \frac{1}{2}$ feet above the original level, and is mostly composed of small pieces of broken marbles of different varieties. It was veneered with marble, one side comes up close to the straight wall, of which 19 feet remains; it was originally 25 feet long. The opposite side is 2 feet from the hemicycle wall, which is 39 feet long and $10 \frac{1}{2}$ feet high, and is broken down at each end. The Rostra platform extends 16 feet 10 inches on each side of the hemicycle recess.

We must now turn to the historical records. Livy, who passed most of his life in the court of Augustus, and was 15 years of age at the time, says, Ep. 116, "The body of Cæsar carried through the Campus Martius, is cremated by the people before the Rostra." Suetonius, A.D. 79-135, says, "Both magistrates and functionaries of honour carried the bier to the Rostra in the Forum," Coes. 84. This was from his house on the Via Sacra on: March 17th, B.c. 44. He was murdered on the 15 th. Appian (about the same date) says, B.c. II, 42, "Piso (his father-in-law) caused the body to be brought to the Forum, and placed it before the Rostra." It was from here that Anthony delivered his tamous speech and soliloquy to Cæsar's budy, then, as Appian records, " he stretched out 
his hand towards the Capitolium (Temple of Jupiter), and in a loud voice invoked Jupiter." This demonstrates that Anthony was facing towards the Capitoline Hill, and the only Rostra that did so was the Rostra Julia. Pliny, X, 60 , speaks of it as looking towards the Forum.

"Suddenly two of them, girt with swords, and carrying two javelins, set it on fire with lighted candles." Used in funerals then as now. Suetonius, Cres. 84. "They carried the body from the Capitol back to the Forum, and in that place, in sight of the old monumental Regia of the Romans, gathering together all the wood from the seats in the Forum and neighbourhood, raised a magnificent pyre, upon which placing the body, they set it on fire. In that place at first an altar is erected, now the Temple of Cæsar himself, is placed by Octavius." Appian, B.c. II, 42. "Caius Amatius (Marius, a supposed kinsman of Cresar's) constituted an altar before the pyre. The people demanding the magistrates to consecrate the Altar of Amatius. and to perform the first sacrifices to Cæsar." Appian, B.C. III, 1.

"Afterwards a solid column, nearly 20 feet high, of Numidian marble, was erected in the Forum, and inscribed, PARENTI PATRIas (To the Father of his country). At which for a long time they sacrificed, made vows, and settled disputes in which they swore by Cosar." Suetonius, Coes. 85. "After the taking of Perugia (B.c. 39) 300 prisoners were selected from the rest and slaughtered, like victims, before an altar raised to Julius deified upon the Ides of March," (15th) Suetonius, Aug. 15. The altar was not erected till after the 17 th.

"The people erected an altar in that place where the pyre had been (in the meantime his freedmen took away the ashes and placed them in his family sepulchre), and established sacrifices upon it, and burnt victims to Cæsar, as to a god, but the consuls overturned the altar." Dion Cassius, XLIV, 51. "The same men were erecting a tomb in the Forum, who had performed that irregular funeral.": Cicero, Phıl., I, 2.

"When you yourself (Anthony) were absent, what a day was that for your colleague (Dolabella, Cicero's son-

1 Horace, O. I., 2, gires it the same title. 
in-law) when he overturned that tomb in the Forum, which you were accustomed to regard with veneration." Cicero, Phil., II, 42. Dolabella was chosen consul instead of Cresar on March 16th, B.c. 44. He pulled down the altar of Amatius a short time afterwards. It would seem that the altar and column are the same thing, for all the authors call it an altar except Suetonius, who says it was a column. Suetonius says they offered sacrifice there for a long time, and instances the slaughter of B.c. 39 already quoted. He must mean by this at the Temple erected afterwards. "Augustus erected a temple in the Forum in. that place where he (Cæsar) was cremated." Dion Cassius, XLVII, 18. It was commenced B.c. 33 and dedicated August 18th, 28 в.C. (A.U.C. 725 ).

Appian and Dion Cassius both say the Temple of the deified Casar was built in tnat place where he was cremated. This is not strictly correct, for he was cremated in front of the Rostra, whilst the Temple is behind the Rostra. In that place means perhaps in the Forum, not the exact spot of cremating. It follows that the body was cremated in front of the Rostra in the hemicycle recess, the walls of which show distinct traces of fire along the lower courses of stones. In this recess the altar, in the form of a column, was erected on the octagonal base now discovered; this was pulled down by Dolabella in a very short time, before the murder of Cicero in 43 в.C.

When Augustus erected the Temple Tomb he built it up close to the rear of the Rostra, which formed a rectangular platform along the front of the Temple; and he enclosed the hemicycle recess by building a wall across the opening, thus giving the front of the Rostra Julia a straight line, as represented on coins, and on the Relief of Marcus Aurelius in the Forum; and upon it he fixed the rams (Rostra) of Mark Antony's fleet, captured at the battle of Actium B.c. 30. Dion Cassius, LI, 19.

\section{Tine Tomb of Faustulus.}

In ascending the rather late road passing under, the Arch of Septimius Severus some narrow pieces of white 
marble were noticeable forming part of the road near the edge of the silex pavement on the right, about 75 feet from the arch and 150 feet out from the front of the Senate House, S. Adriano. On January 10th the excavations along the north side of the Forum revealed the fact that this late road continues all along that side, and that the narrow pieces of white marble formed part of the top of a balustrade 2 feet 3 inches bigh, formed with four slabs of marble, enclosing a sacred area paved with irregular blocks of Nero Antico marble. The area is 12 feet by 12 feet and may have been somewhat larger, the balustrade being on its south side, with traces of its existence half-way along the west and east sides; the remainder of these sides and the north side have no traces of the balustrade left. The slabs forming the balustrade originally formed part of the facing of the base of the Arch of Severus, and are from 5 to 6 inches in thickness, thus demonstrating that their present use is very late. They are inserted in a groove cut in slabs of travertine stone which bound the black marble paved area, and is raised 12 inches above its level. This south balustrade is not straight, but curved inwards. The whole was covered over when the late road was formed to pass under the Arch of Severus, probably in the sixth century. In front of the slabs, south side, a gutter is cut in the travertine stone base as though for drainage purposes. The pavement is of black marble with veins of white, known as Nero Antico, from Tænarium in Laconia, now called Cape Matapan. Pliny, XXXVI, 29, says, "There are black stones (Nigri) which are esteemed as marbles, the Tænarian for example." Some small fragments of similar marble were found at the recent excavations of the Rostra Julia, and a large slab, broken and scarred, is on the east side of the Temple of Castor and Pollux. The slabs of the area rest on made earth. Festus, the fourth century critic, says, "The Black stone in the Comitium signifies a mournful place to others, destinated for the death of Romulus, but did not happen to be so used, but there is buried Faustulus, who brought him up. The tomb to have been there of old Quintilius, $\mathrm{Ti}$. . . From whose family, it is said, the party who followed Romulus had from him even the name 
Quintilia." " He laughed, and was pained that Remus and the Fabii had been able to win, his Quinctilii had not been able." Ovid, F 2,377.

Faustulus was killed in the dispute between the brothers, before the building of the city, so Festus is in error in connecting the spot where they intended to murder Romulus with the tomb of Faustulus. When Faustulus was killed the Comitium was outside the city bounds, and so he could have been, and according to Dionysius, I, 87, was buried there. "It is said by some that the lion of stone, which stood in the Comitium of the Forum, near the Rostra, was placed over the body of Faustulus, where he fell, and had been buried by those who found him." Plutarch, however, says he was buried on the Remuria with Remus. "Hostus Hostilius, the grandfather of Tullius Hostilius" (who fought with the Romans against the Sabines, Livy, I, 12 and 22), "was buried in the principal part of the Forum, and honoured by the kings (Romulus and Tatius) with a column, and an inscription testifying to his valour." Dionysius, III, 2.

Helenius Acron, an interpreter of Horace in the fifth century, says, Ep. XVI, 13, "Varro says, "The tomb of Romulus before the Rostra; where within his memory two lions have been erected by a degree. From whence is made funeral orations as before the Rostra." This passage does not exist in any of Varro's extant works, but if he says so, either he or his quoter have written Romulus for Faustulus, for Romulus had no tomb, but, according to all the historians, ascended to heaven.

Horace in his sixteenth Epode, 11, says :-

"Alas! the victorious barbarian shall stand upon the ashes of the city,

And the horseman shall smite it with sounding hoofs:

And will insolently disperse, horrible to see!

The bones of Quirinus which are free from the wind and sun."

This is a hyperbole, poetry. Horace does not mean to infer that they possessed the bones of Romulus in his day. His commentator, Pomponius Porphyrionius, of the sixth century, says, "This is said as if Romulus might be buried, not carried off or dispersed to the heavens. For Varro says, " the sepulchre of Romulus to have been 
behind the Rostra." Both these authors agree that Varro says the sepulchre of Romulus was in the Forum, but they materially disagree in its position. Acron says pro rostris, Porphyrionius post rostra, showing that they did not quote from the same manuscript. In fact, the black marble pavement found is, post, behind the site of the original rostra. Neither of these commentators speak of the sepulchre from their own knowledge; whether of Romulus or Faustulus; that of the latter having been where was afterwards the Comitium, and in evidence in the dars of Varro and Dionysius, commemorated by a lion or lions. Neither the Notitia of the first part of the fourth century, nor the Curiosium Urbis of the second part of the fourth century, mention any tomb in the eighth or Forum region, though both enumerate the House of Romulus on the Palatine, which did not then exist, and the tomb of Titus Tatius (Armilustrium) on the Aventine. Plutarch, Rom. 23. So it is evident that the memory of a tomb on the Comitium had passed away in their day; till the Mirabilia Urbis Romce of the twelfth century identified the Pyramid tomb of Honorius, A.D. 423, near the Castle $\mathrm{S}$. Angelo, as the Tomb of Romulus, and it is so represented on the bronze doors of St. Peter's by Antonio Filarete in 1447.

What reasonable explanation call we give of the sacred enclosure recently uncovered? is now the question.

\section{TiIe Mundes.}

That this enclosure was something venerated up to a late period is evident from the fact that it is enclosed with slabs taken from the comparative recent Arch of Severus, and so respected till buried under the late road, formed, we believe, after the sacking of Rome by the Goths under Totilia in 546 or 549 .

We think this sacred enclosure to have been the Mundus, or sacred foundation pit, made at the first enlargement of the city when the Palatine and Capitoline hills were enclosed. Dionysius, II, 66. "A circular pit was dug about what is now called the Comitium, and the 
first-fruits of everything that is reckoned either good by use or necessary by nature were cast into it, and then each party (Romans and Sabines) bringing a small quantity of the earth of the country from whence they came, threw it in promiscuously. This pit had the name of Mundus, the same with that of the Universe. In the next place they marked out the citv, like a circle, round this centre." Plutarch in Romulus. Ovid, F 4, 821, speaking of the Mundus of Roma Quadrata, which still exists upon the Palatine, says :-

"A pit is made down to the solid (clay or rock). All kinds of (first) fruits are thrown to the bottom,

And earth obtained from the neighbouring soil.

The pit is filled in with earth, and when full an altar is set up,

A flame kindled and the new hearth is served."

In continuing the excavations on January 21 st, 5 feet from the black marble area, off its north corner, but within the north line, a pit was discovered 5 feet in diameter and 15 feet deep, filled with moist black earth, decayed vegetation; in clearing it out it was found to contain clear water, percolation, which was pumped away into a branch of the Cloaca Maxima. It is lined with pieces of marble and travertine, old material re-used. On January 26th a dozen terracotta vases and jugs, many broken fragments of others, and a piece of rare African marble were extracted from the bottom of the pit. Perhaps this pit is the actual Mundus described by Plutarch, and upon the black marble area was tho altar similar to that spoken of by Ovid, the gutter being the trough to carry off the blood.

It was closed with a stone (Manalis Lapis), "Yet the dismal lower gods may open in a manner the door when the Mundus may be opened." Varro, quoted by Macrobius, Sat. I, 16. Festus says, "The Manalis Lapis was thought to be the mouth to Orcus (Pluto) by which souls passed from the inferior to the superior (world) who are called ghosts" (Manes). He quotes Capito Atecus for its being open three times a year, but omits to mention the second occasion, which is supplied by Paul the deacon. On these occasions offerings were thrown in, and the first-fruits were renewed. 
August 24th. The day after the Volcanalia, August 23rd.

October 5th. The third day before the Nones of October.

November 8th. The sixth day before the Ides of November.

This was probably part of the area called the Vulcanal, " above the Comitium," where grew the lotos-tree which spread its roots as far as Cæsar's Forum, Pliny, XVIII, 86, and on which was " the altar to Vulcan, upon which live fish taken from the Tiber were sacrificed in propitiation for human souls." (Festus.) This part of the Forum had been subject to volcanic action, and so the Altar of the Mundus may have become identified with Vulcan. Romulus and Tatius held their assemblies in the area of Vulcan, which stands a little above the Forum (Dionysius, II, 50), and he also tells us that Romulus had his judgment seat in the most conspicuous part of the Forum, and refers to a legend that Romulus was murdered there, II, 56, which is also mentioned by Plutarch. "The Senators, who were convened in the Temple (? area) of Vulcan, fell upon Romulus and killed him, on the 7th of July as it is now called, then Quintilis." Gruter, LXI, 2, gives the fragment of an inscription of B.c. 8, found in 1554 near the Arch of Severus, which corresponds with a complete inscription of B.c. 9, found in the Forum at the Temple of Castor in 1548, then called Saturn, in which the volcano is mentioned. All this accounts for the connection of this part of the Forum with Romulus, whose statue stood in a bronze chariot which he had consecrated in the area of Vulcan, having captured it from Cameria. (Plutarch in Romulus.)

\section{Historical Pedestals.}

Further explorations during May show that the black marble pavement, discovered in January, rests on dumping 5 feet above a platform of tufa, 1 foot high, but at a different plane.

Remains of two blocks of tufa with mouldings exist 
on the east end forming part of a pedestal 9 feet long, 4 feet 3 inches wide. There is a similar pedestal at the west end. Between the two pedestals is a space 3 feet 3 inches wide, occupied at the north end by a square, isolated, block of tufa. Close by, beyond, at a different angle, is a square base upon which is a truncated column of tufa 2 feet 81 inches high. These were, we believe, occupied by the Lion of Faustulus, Dionysius, I, 87, the Lion of Quintilius, Festus, Acro quoting "Varro; and the Column of Hostus Hostilius," Dionysius, III, 2, Livy I, 12 and 22 ; all erected before the union of the Palatine and Capitoline hills into one city, 748 B.c. Another extraordinary proof of the truth of the written history of early Rome!

In the dumping between the black marble pavement, the Mundus, and the tufa platform, six bronze statuettes were extracted, one of them being that of an augur, the others Lares, a terracotta statuette with the arms down by its sides, and numerous small terracotta vases and bronze fragments have been found. The whole of the dumping has not yet been examined; the marble pavement has been underpinned so as to preserve it, so more objects may yet be found.

Numerous bones of sheep, boar, and ox were also discovered close by. This points to the site of the sacrifice of the Suovetaurilia, when Camillus purified the city after he had delivered it from the Gauls ("Next Camillus sacrificed to the gods, and purified the city, in a form dictated by the pontiffs," Plutarch in Camillus), instituted by Servius Tullius, Livy, I, 44, and performed by Constantine in 316 A.D. as recorded in relief on his pedestal in front of the Rostra Vetera; and twice on the reliefs of Marcus Aurelius close at hand.

\section{The Rostra Vetera.}

The have much pleasure in announcing the discovery in the Forum of some remains which we have demonstrated to be the Rostra Vetera. Livy, VIII, 14, tells us that in 3.8 B.c. "a Suggestum (pulpit) was erected in the Forum and propitiously adorned with the prows of the captured fleet of the Antiates; the same was called a 
Temple and Rostra." This seems to have been the rebuilding, or an addition to an earlier suggestum, for he uses the word Rostra in anticipation when he speaks of the statues of the four murdered ambassadors being placed in the Rostra in 438 в.c. Varro, L, L, 14, says, "the Rostra was in front of the Curia." (S. Adriano.) Cicero, pro L. Flaccus, 24, says, "The Senate-house commands and surveys the Rostra." Asconius, Cicero pro Milone, says, "Then indeed the Rostra was not in that place where it is (they are) now (the Rostra Julia was an innovation) but on the Comitium almost adjoining the Curia." Dion Cassius, XLIII, 49, also says the same thing, referring to another change. The Rostra of his day was the new one, Rostra ad Palmam, erected by Severus on the south side of his arch. Asconius, Pro Milone, 15, says, "that when the body of Clodius was cremated and the Senate-house burnt down, that the tribunes M. Plaucus and P. Rufus had to flee from the Rostra on account of the heat." This also shows that the Rostra could not have been far from the Curia or Senate-house.

The marble slabs on the south side of the Niger Lapis (the Mundus) have been found to stand on a hemicycle wall of travertine 6 feet wide, as revealed by the excavations made towards the end of April, the curve of which is 86 feet long. The upper part of this construction is composed of blocks of travertine stone, the lower part of the western half of blocks of tufa, and 23 feet of the eastern half is of opus incertum; 3 feet in front of this is another curved wall of opus incertum; both these walls show traces of having been coated with stucco. This construction is a work peculiar to the second century B.c. In the front centre of this curved wall, and 2 feet below the top of it, are the remains of an irregular platform of tufa stone, so constructed that it has the appearance of a triangle jutting out from the curved wall, the south point of the platform being $1 \frac{1}{2}$ feet from the centre of the hemicycle wall. The west side of this platform also shows construction of opus incertum, repairs. The north side of this platform has been traced under the Niger Lapis. We believe that this tufa platform is the original Suggestum, and that the hemicycle wall is the 
substructure of the Rostra. It answers topographically to all the passages above cited, as being on the Comitium and in front of the Senate-house. Frontinus, Ep. I, 2, says, " the top of the Rostra is but little superior to the Forum and Comitium, rather lower (down) even are the prows of the ships of the Antiates. This lower platform is spoken of by Livy, VIII, 33, in B.c. 323, as where private citizens had liberty of speech. " "Papirius ordered Fabius to be taken down from the Rostra to the lower part." "Cæsar when Prætor had ordered Q. Catulus to speak from the lower place, he now brought Vettus on to the Rostra." Cicero, Ad Att., II, 24, 3. "Whether it speaks from a lower, or an equal, or a superior place." Cicero, de Oratore, III, 6. This lower place in the Rostra Julia is an exedra; there Cæsar's body was cremated. Upon this lower tufa platform, close up to the curved wall, are three blocks of peperino (Alban) stone upon which are two circular indentations, 2 feet in diameter, $1 \frac{1}{9}$ feet apart. The first is one foot to the east of the meridian line; this is probably the site of the sundial of Marcus Philippus, 163 B.c., and the more easterly marks that of M. Valerius Messala of 262 B.c., which Pliny, VII, 60, says was brought from Catina in Sicily, but was not exact. This was owing to the fact that Catania is 3.25 south and 2.34 degrees east of Rome. The south point of the tufa platform in front of the curve is S.S.W., $4 \frac{1}{2}$ feet west of due south, as proved by an observation made by the authorities on May 2nd. Pliny's description, VII, 60, of how "the Accensus (crier) of the Consuls proclaimed the hour of noon, as soon as from the Senate-house he caught sight of the sun between the Rostra and the Græcostasis" (which was to the right of the Curia), exactly tallies with this spot, as we have often demonstrated.

This discovery finally does away with the erroneous opinion, held by so many, that the Rostra ad Palmam, on the south side of the Arch of Severus, was the Rostra Tetera, and which we have always maintained was erected by Septimus Severus when he laid out the Forum anew after the earthquake and fire of 192. The last historical notice of the Rostra Vetera is by Spartianus when he tells us Didius Julianus addressed 
the people in A.D. 193, "from the Rostra in front of the Curia."

A denarius of M. Palikanus of the Lollia gens represents this Rostra; he was an orator, Cicero, Brutus, 62, and tribune of the people, B.c. 69 , when Pompey restored the Tribunitial power, hence the head of Liberty on the obverse of the coin. Five arches are represented as springing from columns, supporting a curved parapet on which is a square desk or table. The rams of three vessels are shown obtruding from the base of the columns outwards, the concave of the curve being towards the spectator, giving the idea that a person could see through the arches from the Senate-side towards the Forum.

From this Rostra Cicero made many of his famous orations, and upon it his head and hands were exposed after his murder, which more people came to see than went to listen to his voice. 
To face poge 319

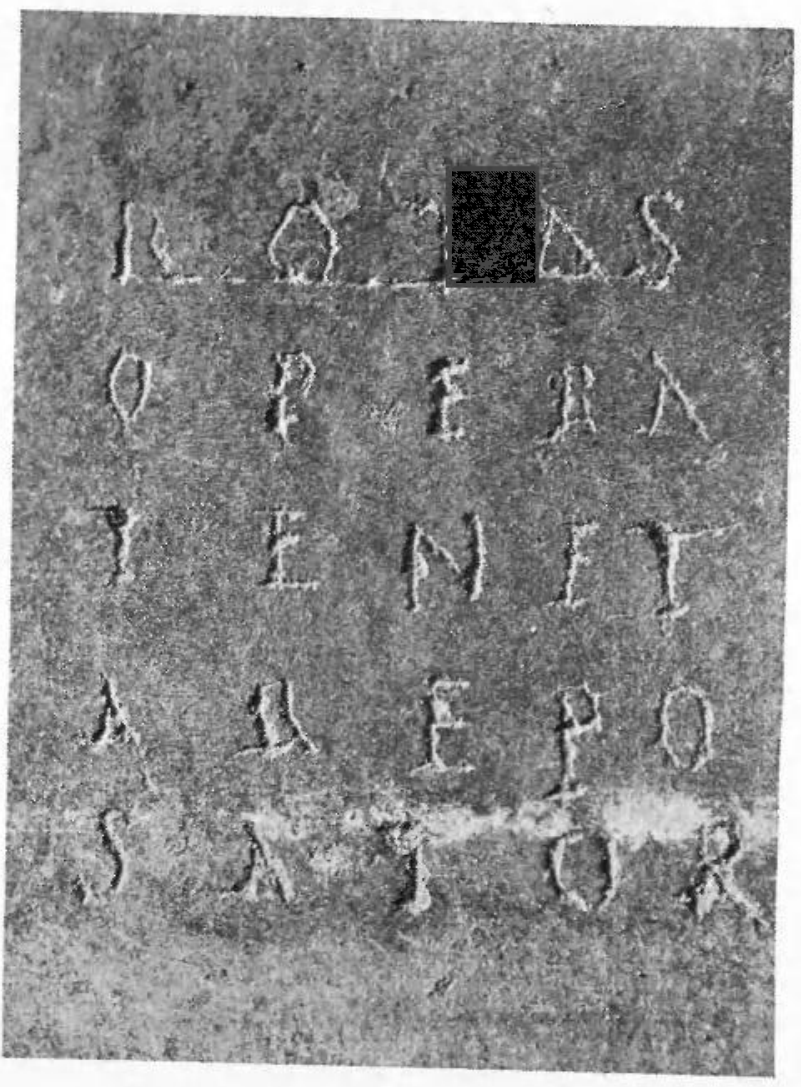

